IRSH 49 (2004), Supplement, pp. 65-86 DOI: I0.1017/So02085900400I646

(C) 2004 Internationaal Instituut voor Sociale Geschiedenis

\title{
Reforming Mysticism: Sindhi Separatist Intellectuals in Pakistan
}

\author{
OSKAR VERKAAIK
}

Summary: This article examines the revival of Sufism and mysticism by the Sindhi separatist movement in South Pakistan. It explores the emergence of a network of young intellectuals from rural and mostly peasant background, and focuses on two pioneers of Sindhi nationalism and Sufi revivalism: G.M. Syed and Ibrahim Joyo. Influenced by Gandhian as well as Marxist ideas on social reform and national identity, these two leaders transformed the annual urs celebration at local shrines into commemorations of the martyrs of Sindh. The article traces their relationship as well as their pioneering role as political leaders, education reformers, and teachers. Analysing their ideas as a particular form of Islamic reform, the article discusses the way they adapted and innovated existing cultural ideas on Islamic nationalism, ethnicity, and social justice.

In the late I960s and early I970s a rebellious movement emerged in Sindh, the southern province of Pakistan, which protested against the military regime, and later, after the first democratic elections in the history of Pakistan, called for the independence of Sindh. Although Pakistan is now widely associated with radical Islamist movements and authoritarian military regimes, this Sindhi movement does not fit in this picture at all. Its two main ideologues were a neo-Gandhian, wearing white clothes while writing treatises on the meaning of mysticism, and a Marxist struggling for the moral and social elevation of the local peasant population. The name of the former was G.M. Syed, the latter was called Ibrahim Joyo. The former was a well-known politician during the times of independence and a member of an aristocratic landlord family. The latter was the son of a peasant and one of the very few of his generation who had got the opportunity to pursue higher education. They had several things in common, for instance their physical appearance, which resembled the humble, homespun fashion of a disciplined vegetarian cultivated by Mahatma Gandhi. Both of them were concerned with the place of Sindh within Pakistan, and together they located the basis of the province's unique position in Pakistan in a reformed Sufism for which they were themselves responsible. Their reformulation of Sufism was a radical break with traditional Sufism, just as most forms of Islamic reform radically 


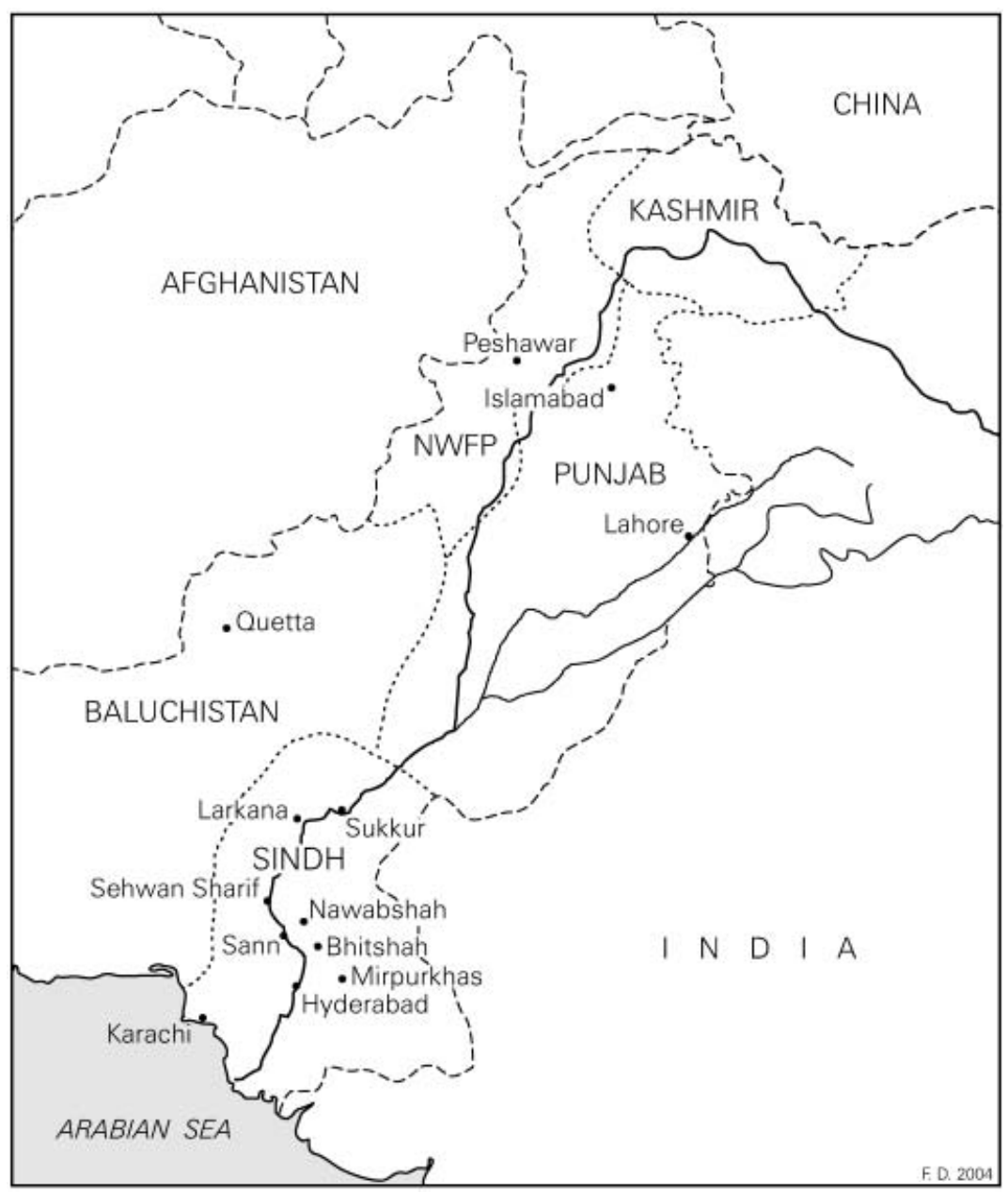

Figure r. Pakistan, with the region of Sindh.

differ from tradition. This contribution focuses on these two intellectuals, the peculiar form of Islamic reform they developed, as well as the context in which they operated.

I take Islamic reform as a response to a globalizing trend that starts with European colonialism and imperialism and continues after decolonialization. ${ }^{\mathrm{I}}$ Part of this globalizing trend is the distribution of ideas, often in modern educational institutions. Islamic reformists have made use

I. See François Burgat, Face to Face with Political Islam (London, 2003), which analyses today's political Islam as a phase in a continuing process of decolonialization. See John Gray, Al Qaeda and What It Means to be Modern (London, 2003) for a provocative analysis of political Islam and today's globalization. 
of these ideas while rejecting or criticizing them and they continue to do so. ${ }^{2}$ While there is increasing academic consensus on these general views, less work has been done on the emergence of intellectual networks or milieus, ${ }^{3}$ which critically engage with the influx of new ideas and ideologies. In this paper, I am especially interested in the emergence of new networks of political activists and Islamic reformists in relation to the introduction and spread of secular education.

This article is structured as follows: after some introductory remarks about the relationship between secular education and new forms of contentious politics framed in the language of Islam, I briefly discuss the setting of my case study, which is the province of Sindh in Pakistan. I introduce the various forms of Islamic reform in Pakistan and how these are related to the discourses of nation and ethnicity in Pakistan and particularly in Sindh. Next, I look at the secularization of education during the colonial period. The next sections focus on the main leaders of the Sindhi separatist movement, namely G.M. Syed and Ibrahim Joyo. By way of short life stories, based on written sources and interviews I had with Joyo, relatives of G.M. Syed, and followers of both men, I illustrate how these men formulated a reformed notion of Sufism, which radically differed from the folk Sufism of the rural areas, and which became the basis of a Sindhi separatist movement that gained much influence among the Sindhi population in the I960s and I970s. Throughout these life stories I will pay specific attention to how these two men used and reformed education as part of their political struggle.

\section{ISLAMIC REFORM IN PAKISTAN}

Of crucial importance for the rise of Sindhi separatism ${ }^{4}$ was the introduction and spread of secular education. In that respect, it resembled

2. See Partha Chatterjee, Nationalist Thought and the Colonial World: A Derivative Discourse? (London, 1986); and idem, The Nation and its Fragments (Princeton, NJ, 1993) for an analysis of how Indian nationalism criticized colonial rule while using and reshaping liberal and Orientalist traditions. Chatterjee's work is especially relevant in my case as Indian nationalism and Islamic reform mutually influenced each other, leading to Muslim nationalism and the demand for an independent Pakistan. Olivier Roy, The Failure of Political Islam (Cambridge, MA, 200I); Gilles Kepel, Jihad: The Trail of Political Islam (London, 2002); Seyyed Vali Reza Nasr, The Vanguard of the Islamic Revolution: the Jama'at-i Islami of Pakistan (London, I994), and others have emphasized the influence of Marxism and Leninism on today's Islamism, as well as how these influences has been turned into a critique of Marxism.

3. I prefer the terms network and milieu to community here because the connotation of the term community as a boundaried social unit is not entirely adequate. Although the term community may be useful in the case of militant political organizations - see David Apter, The Legitimization of Violence (London, 1997) - the intellectual circles connected to these organizations are networks or milieus rather than communities or organizations.

4. The Sindhi movement emerged as one of the most vocal parties in the popular uprising against 
the development of other forms of Islamic reform. Indeed, secular education, as a major vehicle for modernization, has had many unexpected consequences, including the rise of political Islam. As Oliver Roy has argued for recent trends in Islamic reform, the "the cadres of the Islamist parties are young intellectuals, educated in government schools following a Western curriculum".

The link between Islamic reform and secular education is not new. The success of Islamism in universities and other institutions of higher education in countries like Egypt, Algeria, Pakistan, and Turkey is rather the most recent manifestation. In fact, this is not surprising, since one of the main aspects of Islamic reform is the democratization of religious authority. Throughout the Muslim world, Islamic reform since the nineteenth century has been initiated by intellectuals not belonging to the milieu of the traditional ulama, that is, the body of lettered men who dominated education and intellectual production in theological schools and universities known as madrassabs. Whereas these ulama adhered to one of the four established legal schools (Shafii, Malik, Hanafi, and Hanbali), Islamic reformists in the nineteenth century called for the right to individual interpretation (ijtehad) of the founding texts of Islam (Quran and the Sunna) without regard to the tradition of these four legal schools. Reformists were equally critical of the Sufi brotherhoods (silsilab), which to them also constituted traditional authoritative bodies responsible for the decline of Muslim power and culture. Islamic reform, then, generally took place only outside the madrassabs and the brotherhoods. Its main protagonists were intellectuals educated in modern educational institutions.

The study of Islamic reform in Pakistan primarily focuses on two such traditions. First, the interpretation of Islam as an essentially progressive religion, which, in its truest form, promotes Muslim nationalism, social equality, and scientific inquiry, has become highly influential in the Pakistani intellectual, political, and military elite. This tradition harks back to the Muhammadan Anglo-Oriental College, later University, of Aligarh

the military regime at the end of the I960s. It consisted of several organizations, including political parties, student organizations, and labour unions. It took part in demonstrations and strikes against the government. In the late I960s and early 1970s, and again in the late I980s, several Sindhi groups regularly clashed violently with so-called Muhajirs, migrants from India who constitute the second-largest ethnic group in Sindh since the time of the Partition. For a fuller discussion of this polarization between Muhajirs and Sindhis, see Oskar Verkaaik, Migrants and Militants: "Fun" and Urban Violence in Pakistan (Princeton, NJ, 2004). After the I97 I national elections, the Sindhi movement grew more radical, calling for an independent Sindhi homeland under the name of Sindhudesh in 1973. Although most Sindhi ethnic and/or separatist organizations have refrained from political violence, other groups have occasionally opposed the central government with violence, especially during the 1983 uprising of the Movement for Restoration of Democracy (MDR).

5. Roy, The Failure of Political Islam, p. 49. 
in north India, established in I875, and also to the works of Muhammad Iqbal, the intellectual founder of Pakistan. Second, the interpretation of Islam as essentially opposed to nationalism and secularism has informed anti-elitist, Islamist groups and parties, calling for the sovereignty of the shariat and for Islam as a total way of life. Although intellectual developments are never unilinear, this tradition is influenced by the theological academy (dar-ul-ulum) of Deoband, north India, established in 1867 , and by the writings of Abul Ala Mawdudi, the founder of the Jamiat-i Islami. ${ }^{6}$

However, it is often overlooked that Pakistan has produced a third variety of Islamic reform, which is the reform of mystical traditions, or Sufism. Although Sufism is notoriously difficult to describe - it has been labelled as the "esoteric" dimension of Islam and the "folk" tradition of Islam - Sufism in South Asia mostly relates to brotherhoods (tariqa) connected to the shrines of holy men, which have been, and still are, important centers for popular piety. ${ }^{7}$ As such, Sufism is widely seen as juxtaposed to the reform and modernization of Islam. Yet, precisely in the process of defining Sufism as the quintessential tradition of south Asian Islam, Sufism ceased to be merely a religious practice and became an object of intellectual activity. This intellectual trend, then, rejects the two other forms of Islamic reform as foreign, and looks instead for an indigenous, folk, sometimes ethnic, form of Islam. Downplaying the transnational character of Sufi brotherhoods, such an indigenous Islam is found in reformed Sufism. ${ }^{8}$

In the I960s and I970s, this reformed Sufism was a powerful ideological force behind left-wing and ethnic movements that protested the modernizing and centralizing policies and ideologies of the state, including the independence movement in East Pakistan that led to the founding of Bangladesh in 1971. 9 In order to prevent the fragmentation of Pakistan in various ethnic groups, the central government, during the early decades of Pakistan's existence, deemed it necessary actively to promote a modernized form of Islam as the basis for a national identity. Hence, the infamous one-unit scheme, which brought the provinces directly under the rule of the central government, went hand in hand with efforts to purify Islam from what was condescendingly seen as regional folk traditions,

6. See David Lelyveld, Aligarh's First Generation: Muslim Solidarity in British India (Princeton, NJ, I978) and Barbara Dale Metcalf, Islamic Revival in British India: Deoband, I860-1900 (Princeton, NJ, 1982) for the various nineteenth-century educational centers in Muslim South Asia.

7. Katherine P. Ewing, Arguing Sainthood: Modernity, Psychoanalysis, and Islam (Durham, 1997), and Pnina Werbner and Helene Basu, Embodying Charisma: Modernity, Locality and the Performance of Emotion in Sufi Cults (London, 1998).

8. See Burgat, Face to Face with Political Islam, for a related argument on the Maghreb.

9. Asim Roy, The Islamic Syncretistic Tradition in Bengal (Princeton, NJ, 1983). 
superstition, and non-Islamic elements. Particularly the well-known institution of the pir - that is, the descendents of the founders of Sufi brotherhoods, who embody the mystical powers attributed to these founders - was seen as a hindrance to the spread of a modern Islamic mentality. These pirs, often claiming to be descended from the Prophet Muhammad, often held powerful positions as spiritual leaders as well as landlords. In order to undermine their authority, the modernizing elites condemned the spiritual and healing practices of the pirs as backward and impure forms of Islam. The Sindhi turn to folk Islam, then, was partly a matter of reversing the stigma of backwardness. In the process, however, folk Islam was no longer seen as primarily connected to the power of the pirs, but reformed and refashioned into a deep-running inclination towards mysticism and Sufism. ${ }^{10}$

In the late I960s, the combination of ethnic identity and Sufism proved to be attractive to student activists and others critical of the military regime. The flirtations with the folk, the traditional, and the mystical formed a powerful critique of the modernism and authoritarianism of the central government. The Sindhi movement was one of the main contributors to the popular protest that led Pakistan into a major crisis, resulting in the first democratic elections in 1970 and the foundation of Bangladesh in 1971. Following the model of the Bengalis, the Sindhi movement led by G.M. Syed called for the independence of Sindh in 1973 . Confronted with similar ethnic movements in other parts of the country, the winner of the 1970 elections, the Pakistan People's Party, headed by Zulfiqar Ali Bhutto, acknowledged ethnic identity as a legitimate form of loyalty within the context of Pakistan, partly giving in to the demands of the ethnic movements. This was a break with earlier state discourse in which ethnicity and Islam were seen as incompatible. ${ }^{\text {II }}$ In this respect, the Sindhi movement has remarkably influenced state ideology, even though the separatist parties have never managed to win real power.

The Sindhi separatist movement represents a particular form of Islamic reform because its main proponents were popular intellectuals. That is to say that they neither belonged to the ranks of traditional religious leaders nor to the mainly city-based middle-class intellectuals who had been engaged in earlier forms of Islamic reform. Furthermore, the Sindhi separatist intellectuals emerged on the scene after independence, when Islamic reform, itself developed in reaction to European colonialism and orientalism, ${ }^{\mathrm{I} 2}$ had left its mark on the dominant ideology of Pakistani

ı. Verkaaik, Migrants and Militants: "Fun" and Urban Violence in Pakistan, ch. I.

I . Oskar Verkaaik, "Ethnicizing Islam: 'Sindhi Sufis', 'Muhajir Modernists' and 'Tribal Islamists' in Pakistan”, (paper presented at Columbia University, New York, 2003).

I2. See Peter van der Veer, Religious Nationalism: Hindus and Muslims in India (Berkeley, CA, 1994) and Carol A. Breckenridge and Peter van der Veer, Orientalism and the Postcolonial Predicament: Perspectives on South Asia (Philadelphia, PA, I993). 
Muslim nationalism. Sindhi separatists intellectuals therefore had to frame their protest within the limits set by Muslim nationalism. Even in rejecting Pakistani Muslim nationalism, the Sindhi separatist intellectuals adhered to the notion that Islam constitutes the basis for national identity. Within these restrictions, however, they designed their own version of Islam, which allowed them to argue for a separate Sindhi national identity based on Sindh's unique experience with Sufism.

In terms of the themes central in this volume, this paper looks at how Sindhi separatist intellectuals appropriated certain aspects of official state discourse in order to pursue their own antistate activities. Whereas dominant Muslim nationalism left no room for ethnic identity within the Pakistani nation, the Sindhi intellectuals challenged this view, not by rejecting the importance of Islam in political discourse as such, but by interpreting Islam in terms of mystical traditions, subsequently linking this mysticism with loyalties of homeland and kinship. Besides appropriating state discourse, they also used and transformed various other discourses present in South Asia, notably Gandhian or theosophical notions on the shared core of all religions, as well as vaguely Marxist notions on feudalism and class struggle. In doing so, they also became cultural innovators producing a new language of ethnic politics eventually adopted by the Pakistani state. As most of these popular intellectuals were educated at institutions of secular education, I will now look at the modernization of the educational system in Sindh.

\section{THE SECULARIZATION OF EDUCATION}

When the British conquered Sindh in 1843 , they found that the syeds played a crucial role in education as men of learning and education. ${ }^{13}$ The syeds ${ }^{14}$ claim to descend from the Prophet's grandsons, Hasan or Hussain. Syeds had an extraordinary powerful position as religious specialists and men of learning in Sindh. The status of the syed community had been enormously enhanced in the eighteenth century when the Moghul influence in Sindh was on the decline and Baluchi kings took over power. These kings relied heavily on the support of the syeds and pirs and granted them various privileges in return. ${ }^{15}$ For this reason, the syeds and pirs enjoyed a much higher status as religious specialists than the ulama did. The latter are associated with theological seminaries, of which there were only few in Sindh prior to the British rule.

I 3. E.H. Aitken, Gazetteer of the Province of Pakistan (Karachi, 1986), p. 472, and H.T. Sorley, Shah Abdul Latif of Bhit: His Poetry, Life and Times (Karachi, 1968), p. 675.

I4. Note that there are various ways of transliteration. Syed can also be spelled as sayad, sayyad, sayyid, seyyid, etc.

is. Sorley, Shah Abdul Latif of Bhit, pp. I54-162. 
Before the colonial conquest, the syed community ran the madrassabs where Arabic and Persian - the latter being the language of administration - were taught. In total, there were six of these madrassabs, which were the apex of the Sindhi educational system. Apart from these madrassabs, there were Muslim primary schools, teaching the Quran, as well as Hindu primary schools, where Khudawadi, the language of commerce, was taught. In addition, many landlords employed private tutors for their children, of which some of the village children could also benefit. Private tutorage and primary education were often funded privately by local landlords and notables and they generally survived the British takeover of power. However, the madrassabs were state-funded, and these funds stopped soon after the British conquest. After five years of British rule, Sir Richard Burton, who then worked as an official interpreter for the British colonial government, remarked that "it is a matter of regret to me that under our enlightened rule, we should have suffered the native places of education to become all but deserted for want of means to carry on the system". ${ }^{16}$

By the time Sindh was conquered, the controversy about the language and education policy in British India had already been decided in favour of those who preferred English, rather than an oriental classical language, as the language of administration and higher education. A new education system was introduced based on the Bombay tradition, meaning that primary education was in the vernacular, while higher education was in English. As a result, Persian lost its status as the language of administration and learning. However, the British did little to promote higher education in Sindh. It was left to the missionaries to establish English schools, which it reluctantly did, particularly in Karachi, which, however, was primarily a colonial city and hardly accessible for most Sindhis. As a result, students who wanted to pursue higher education were forced to travel to Bombay.

Thanks to local initiatives, this situation gradually improved. In I 885 , a Sindh Islamic madrassab was founded in Karachi on the model of the Muhammadan Anglo-Oriental College in Aligarh. Although the school was for Muslim students only, and its name may suggest a traditional Muslim curriculum, in practice it was meant to promote modern secondary education in English. Many of the teachers were in fact Hindus, from Sindh as well as from Gujerat and Bombay. Nonetheless, Sindhi students still had to travel beyond the borders of Sindh for higher education. Till independence, it was common practice for Sindhi students to finish their education in Bombay, the Muslim princely state of Junagadh in neighboring Gujerat, or in Aligarh.

As the highest place of education in Sindh, the Sindh madrassab played 
an important role in the creation of a new group of intellectuals who would form the core of the left-wing Sindhi separatist movement in the r960s and I970s. They were the first generation of students from non-elite village backgrounds who acquired modern education. These students came from Muslim families who had benefited from social transformations during the colonial period. Some had fathers or uncles who had been hired as village government servants (tapedars) by the colonial government. Others were from families who had recently managed to purchase some land, often from Hindu traders and moneylenders. Thirdly, the sons of village headmen (wadero), who acted as intermediaries between the landlords and the peasants, also got access to modern education. All these village boys started their education at village level, sometimes receiving private education from a local Hindu schoolteacher or at a village mullah school (makhtab). If they were lucky, there was a primary school in the vicinity to which they could go, where they received education in Sindhi for up to seven years. To be able to go on to the Sindh madrassab in Karachi, it was essential to have good contacts with traditional patrons such as landlords and syeds. As a result, only a few students who were not from high-caste (ashraf) family backgrounds managed to make it to the Sindh madrassab prior to independence, but of those who did several would join the Sindhi movement that emerged after 1958 .

After the British conquest, Sindh had been ruled from Bombay, but in 1936 Sindh gained provincial autonomy, with the result that the education system and opportunities in Sindh improved. This continued after independence, despite the fact that many Hindu teachers left for India. Primary education was made compulsory in 1940. More primary and secondary schools were opened throughout the province. In 1947, a few months before independence, a university was opened. Originally located in Karachi, the Sindh University was moved to Hyderabad in I95 I.

The establishment of the Sindh University was the major step in the secularization of education, a process that had started with the British conquest that destroyed the local education system in which the syed community played a crucial role. As the West Pakistan Gazetteer of I968 remarked, "throughout [the colonial period] the [local] mullah schools or makhtabs were treated very much as the Cinderellahs [sic] of the educational world". ${ }^{17}$ The syed-run madrassabs or places of secondary education also suffered from lack of funds. Instead a secular system based on the British model was established, a task for which the British colonial government showed little interest, leaving it to the Sindhi cultural elite to set up new schools and colleges. For this reason, the reconstruction of the educational system along secular lines was only seriously taken in hand between 1936 and 1947, when Sindh was no longer ruled from Bombay. 
The secularization of the education system continued after independence, when the British system became the model for the new education system introduced throughout Pakistan.

As the following sections show, the institutions of secular education would become meeting places of new intellectuals, relatively independent of the traditional political and religious elite. They would adopt and reinterpret ideas about freedom, social equality, and social reform, which prevailed throughout south Asia, turning these ideas into a new and powerful frame of contentious politics, which consisted of a combination of Sindhi nationalism, Sufi reform, and Marxism.

\section{G.M. SYED}

Let me now turn to the main figure in this paper, who is Ghulam Murtaza Syed - generally known by his initials in Sindh and Pakistan. He was in many ways a remarkably productive, original, and largely autodidact intellectual, creating his own personal interpretation of Islam out of a range of intellectual influences such as nineteenth-century Islamic reform, Darwinian evolution theory, theosophy, eighteenthcentury Sindhi poetry, Marxism, classical Sufism, German idealism, and probably more. He successfully managed to present this eclectic mix of ideas as the authentic and age-old Sindhi tradition of Islam. At the same time he was an experienced politician, at some point the main protagonist of the Muslim League in Sindh, while later becoming the most vocal and radical critic of Pakistan nationalism. But he became the intellectual leader of a rather small group of intellectuals from village backgrounds an avant-garde or vanguard to some of its members - who, often thanks to G.M. Syed's patronage, were the first of their generation to pursue higher education outside their village or district, and who became his most loyal supporters.

When he died in 1995 at the age of ninety-one, Syed had become Pakistan's most controversial political figure. He had published books and interviews in which he had called Pakistan a mistake. He had argued that Islam acknowledged no borders between Muslims; therefore Islam could never be the basis of a modern state. However, he continued, it is a natural fact that Muslims are divided in historically and geographically determined cultures, but the advocates of Pakistan have not accepted this natural fact. He had criticized the founding fathers of Pakistan - Muhammad Iqbal and Muhammad Ali Jinnah in particular - for their un-Islamic behaviour. He had condemned animal sacrifice, circumcision, and the circumbulation of the Kaaba, that is part of the annual pilgrimage to Mecca, as pagan practices that had perverted the original message of the Prophet. He had called Islam a stage in the evolution of human spirituality rather than the final word of God. He had accepted Buddha, Christ, Gandhi, Jalalludin 


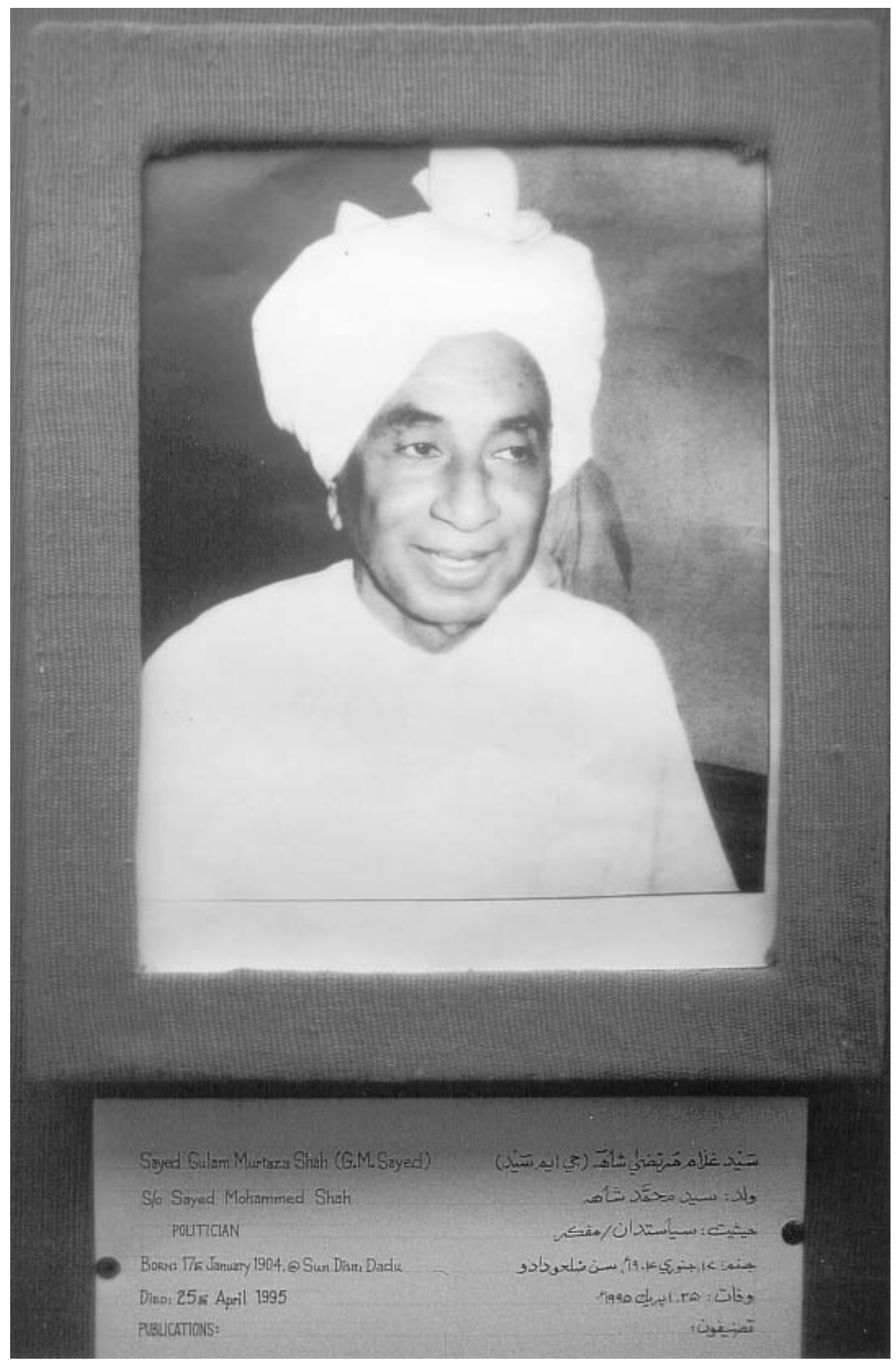

Figure 2. Portrait of G.M. Syed (Sayed) in a photo gallery of Sindhi heroes in the Sindh Museum in Hyderabad.

Photograph by the author 
Rumi, and the eighteenth-century Sindhi poet, Shah Abdul Latif, as prophets of mysticism (tasawwuf), which he considered the final stage of this spiritual evolution. Passages from the Quran, the Bhagavad Gita, the Bible, the Torah, and the Shab-jo-risalo (the collection of verses of Shah Abdul Latif) were read at his funeral. He had been arrested many times and had spent twenty-eight years under house arrest without trial, including twenty-two years between 1973 and his death in 1995. In the Sindh Museum, located on the campus of the Sindh University near Hyderabad, he is remembered as one of the most important figures in the history of Sindh.

According to Hamida Khuhro, a leading historian of Sindh and at some point a political ally of G.M. Syed, 'Syedism' was his first and most constant ideology. G.M. Syed was born in 1904 as the son of a syed landowner in a village known as Sann on the west bank of the Indus. After his father had died when he was two years old, he was brought up with the idea that a syed is a spiritual leader to his people, that is, the peasants (haris) working for him. Rather than the people of flesh and blood working on his fields, however, he soon took the hari as an abstract or imagined category including all landless Muslim peasants in Sindh. He saw the haris as an exploited and backward people, who needed to be freed and uplifted. To him, this was the main task of the syed. The organic bond that he felt existed between the syed and the hari was grounded in a shared spirituality rooted in the soil. This reinterpretation of the syed's task from a local patron to a social reformer was enhanced further when he met Gandhi in I92I, who had come to Sindh to campaign for the Khilafat Movement, expressing solidarity with the Turks in their fight against the European powers. Gandhi advised the seventeen-year-old Syed to wear khaddar (home-spun cloth) and identify with the local people, as Gandhi himself did with the harijan ('untouchables'). Another role model was Khan Abdul Ghaffar Khan, often called the Frontier Gandhi, who led a campaign of civil disobedience mixed with social reform in the rural and tribal areas of the Northwest Frontier Province. ${ }^{18}$ As a junior politician and a member of the Congress Party, G.M. Syed had access to these anticolonial leaders.

The Khilafat Movement meant his entrance into anticolonial politics. But true to his 'Syedism', his first political act was to found a syed committee to urge his fellow syeds to take their leading tasks seriously. Next, he founded a hari committee to protect the peasants from exploitation from Muslim landlords and Hindu moneylenders. At that time, Sindh administratively belonged to Bombay and in 1928 a movement was launched to call for provincial autonomy for Sindh. This movement was crucial for fostering a Sindhi political identity. As initially both

18. G.M. Syed, The Case of Sindh: G.M. Sayed's Disposition for the Court (Karachi, I995), p. I8. 
Hindus and Muslims were involved in this movement, which was supported by the Congress Party and the Muslim League alike, the arguments raised to prove Sindh's cultural uniqueness were not based on Islam. One rather referred to Arabic historical sources that identified the Indus delta as a separate country between Persia and Hind (India). ${ }^{19}$ The archaeological discovery in 1926 of the remains of the Indus Valley civilization in a site known as Moedjo-Daro were also presented as proof of Sindh's historical uniqueness as the land of the Indus. In other words, a Sindhi nationalism already existed prior to the introduction of Muslim nationalism in the late I930s and I940s. This influenced G.M. Syed's notion of Pakistan when he allied himself with the Muslim League in I938. For him, Pakistan was the restoration of a historical-geographical entity, a Greater Sindh, which he argued had once existed on the borders of the Indus and its tributaries. ${ }^{20}$

Sindh won its provincial autonomy in 1936. Muslim-Hindu riots first occurred in Sindh in 1939. G.M. Syed was arrested for being the leader of the rioting Muslim population of Sukkur, a town in Upper Sindh. Later he became the Minister of Education in the provincial government of Sindh and a leading figure in the Muslim League. He also established a school, including a boarding-house for students, in his home village, which became the first Anglo-vernacular school in the vicinity, where both English and Sindhi were used as languages of instruction. Over time, however, he became more of a politician than a social reformer. In his autobiography, which he wrote in the form of a deposition for the court, he mentions several mentors who warned him not to forget his task as a social reformer and spiritual leader. But he admits that he did not yet listen. ${ }^{21}$ In 1945 he left the Muslim League, but he remained part of the Sindhi political elite, that almost exclusively consisted of landlords, syeds, and pirs, together with a few representatives of the up-and-coming Muslim trading castes (Memon, Khoja, Bohra) who had settled in Karachi - the port city, established by the British, and isolated from the province's heartlands by desert areas.

It was only in 1958 when G.M. Syed, in his own words, left party politics behind and returned to his true "faith" 22 of spiritually and economically liberating the rural poor. For some commentators, the

19. The most elaborate treatise arguing for Sindh's separate identity is a pamphlet called A Story of the Sufferings of Sind, first published in 1930 by Muhammad Ayub Khuhro in Hamida Khuhro (ed.), Documents on Separation of Sind from the Bombay Presidency (Islamabad, 1982), pp. 196-254. This text was an early expression of the notion of Sindh as the victim of a series of invasions - Arabic, Moghul, British, Punjabi, Muhajir - which is an important trope in Sindhi nationalism.

20. Riaz Ahmad, Foundations of Pakistan (Islamabad, 1987), vol. 2, pp. 442-443.

21. Syed, The Case of Sindh, pp. 47-49.

22. Ibid., p. 34 . 
incentive for this came from the memory of an unhappy love affair with a Turkish woman known as Mademoiselle Taraki, whom he had met in Bombay. G.M. Syed himself indeed often told his visitors that he learnt his first lessons about true love (ish $q$ ) from her, subsequently sublimating this worldly kind of love (ishq-i mijazi) into a higher state of love (ish $q-i$ haqiqi) for Sindh and the divine. He gives a more profane explanation in his autobiography. The military takeover in 1958 banned all political activities and several politicians, including G.M. Syed, were put under detention. For seven and half years he was under house arrest. In retrospect, he considered this a blessing in disguise as it made him leave "the thorny field of politics".

He made a study of the history of Sufism in Sindh, which resulted in the publication in 1967 of a book called Religion and Reality - originally written in Sindhi, but translated into English and Urdu. In this book he presents an evolutionary theory of religion, distinguishing various stages such as Hinduism, Buddhism, Christianity, Islam, "science", and finally mysticism (tasawwuf) or "natural religion", which fully acknowledges the oneness of being (wabdat ul-wajud). In his interpretation, mysticism goes beyond doctrine and ritual. Hence, there is a mystical core in any religious tradition that remains essentially the same. Mysticism, being universal and eternal, can never be the basis of nationalism. Religious nationalism in any form is a mistake and creates false communities. Although the love for mankind as a whole is the truest form of love, akin to the love for God, mysticism accepts the loyalty to one's family and homeland as genuine incarnations of love. Naturally, nations are based on a shared love for the homeland. Sindh is therefore a natural nation, but Pakistan is an artificial nation. Moreover, he calls Sindh the cradle of mysticism with a long history of religious tolerance and revolt against the tyranny of the ulama and mullahs. In other words, it is Sindh's vocation to protest false nationalism and promote mysticism. ${ }^{23}$

The book caused a scandal and met with several fatwas as well as legal persecution. Nonetheless, it became the basis for the Sindhi revolt against the military government in the I960s, when groups of students and intellectuals took to the streets to call for free democratic elections. After G.M. Syed was released from detention in 1966, he continued his political activities by promoting Sindhi literature, culture, and language. It was a threefold campaign. On "the cultural front" he founded the Sufi Society of Sindh (bazm-i sufia-i Sindh). He also initiated a foundation to promote Sindhi language and literature (Sindhi Abadi Sangat). Finally, he tried to arouse "political and social awareness" among Sindhi students. He noted that "nations had been defeated politically and economically but their intellectuals, working from the fastness of civilization, literature and

23. G.M. Syed, Religion and Reality (Karachi, 1986). 
culture, not only converted political and economic defeat into victory but also overcame their victors". ${ }^{24}$ These intellectuals, whom he called his "friends", ${ }^{25}$ did not belong to the political establishment. They were rather the first generation of students from peasant and artisan background educated in the new secular educational institutions for which G.M. Syed himself was partly responsible. A central figure in this network of young intellectuals was Ibrahim Joyo.

\section{IBRAHIM JOYO AND THE YOUNG SINDHI INTELLECTUALS}

Ibrahim Joyo was born in I9I 5 , twenty miles from the village where G.M. Syed was born. His father was a peasant but also acted as a middleman between the landlord and the other peasants. On top of this, he owned some land of his own. This gave him an important position in the village where the peasants and artisans were Muslims, and shopkeepers and traders were Hindus. The landlord, a syed, was also the spiritual leader. However, Joyo's father died when Ibrahim was two years old. Ibrahim, nonetheless, got the opportunity to go to the primary school in the village. After five years, he went to the school G.M. Syed had founded in his home village. G.M. Syed also arranged a scholarship for him that enabled him to go to the Sindh madrassab in I932. There he stayed for two years, living in G.M. Syed's house in Karachi, known as Hyder Manzil. This house became a meeting place for students connected to G.M. Syed, and later, after 1958 , it would become a center of the Sindhi movement emerging around G.M. Syed and Ibrahim Joyo.

It became Joyo's ambition to become a teacher at the Sindh madrassah himself and he managed to get another scholarship to do his bachelor in teaching in Bombay. During the two years he spent in Bombay, he got in touch with Marxist journalists and writers, writing in English, most of them from Bengal. They were opposed to both the Congress Party and the Muslim League. This was an important influence on Joyo's thinking. $\mathrm{He}$ became a critic of communal politics, that is, the religious identity politics that pitted Hindus against Muslims, and vice versa. True to Marxist doctrine, he considered religion an instrument of class politics and economic exploitation. For him, the main struggle was a class conflict, but capitalists as well as landlords used the religious sentiments of the people in order to keep the underprivileged masses divided. Back in Sindh, he became a teacher at the Sindh madrassah. He also started a magazine called Freedom Calling, which argued for supporting the British during World War II in return for independence. 
In 1947 he published a little book called Save Sind, Save the Continent (From Feudal Lords, Capitalists and their Communalisms), with a foreword by G.M. Syed. In this book he condemns the landlords (zamindar) and pirs for exploiting the peasants. He condemns the peasants for living like slaves, while on their part tyrannizing their women. "The only duty they know is to work like bullocks for their landlords and money-lenders, to touch the feet of their Zamindar-Masters and Pirs, and worship them literally as living gods, and lastly to instruct their children to do likewise". ${ }^{26}$ This is particularly pitiful, he goes on, because these peasants are Muslims and Islam is a liberating religion. He thus gives his own twist to the notion, widespread among reformists of various kinds, that the true message of Islam has been forgotten with the result that the Muslims live in misery. For Joyo, however, the main fight is not with European powers. The main fight is against oppressive landlords, backward spiritual leaders, and Hindu moneylenders, a fight that can only be won if the Muslims return to the Islamic message of social justice and equality.

Besides, Joyo argues in his book, the recent Punjabi settlers, who came to Sindh after the completion of the irrigation works in the I930s that turned vast desert areas into agricultural lands, are to blame for the misery of Sindh's peasants. He blames these settlers for being ignorant of Sindhi culture and especially of the eighteenth-century poet Shah Abdul Latif, who was the first poet to sing in the Sindhi language. He also blames them for obstructing the cultural decolonialization of Sindh after Sindh's provincial autonomy in 1936 . He writes:

Poor G.M. Sayed, when he was the Education Minister, had issued or was on the point of issuing orders that every non-Sindhee in Sind must learn Sindhee within a stipulated period of time. This, at that time, raised such a vehement noise everywhere among the circles concerned, as if somebody was asking them for giving up their religion. ${ }^{27}$

The "circles concerned" were of course the Punjabi settlers.

In short, in Joyo's analysis the notion of class struggle, Islamic revivalism, and early Sindhi nationalism come together in an optimistic belief in "the river of Progress", ${ }^{28}$ in which the Sindhi Muslim peasants constitute the progressive potential, struggling against the reactionary forces of landlords, traditional religious specialists, and recent Punjabi immigrants. Recognizing the class and national differences between Muslims, he also criticizes Muslim nationalism, saying that " $\mathrm{t}] \mathrm{o}$ talk of Muslim nationalism would be as meaningless and self-contradictory as to

26. Ibrahim Joyo, Save Sind, Save the Continent (Karachi, 1947), pp. 103-104.

27. Ibid., p. I 3 I.

28. Ibid., p. I39. 
talk of world-Nationalism, for Islam represents Universalism, and can be embraced by any one of the hundred and one Nations of the world". 29

At the time of publication the book failed to get much attention in Sindh as the group of leftists was still very small. Joyo saw it as his first task to form a revolutionary vanguard of young Sindhi students and intellectuals. "It is to their youth", he writes, "more specially their student community, and to their middle-class Intelligentsia, that a people always turns for rescue, in times of danger, sorrow or distress. In this respect, the people of Sind appear to be a little unfortunate", ${ }^{\circ}$ as there was as yet hardly a Sindhi student community to speak of. His ambition to be a teacher was therefore ideologically informed. At the Sindh madrassab in Karachi, and later at Sindh University in Hyderabad, he left his ideological mark on several Sindhi students from peasant and artisan backgrounds.

One of them was Hyder Bakhsh Jatoi, who became the president of the Hari Committee in I948. He also was a poet, writing poems in Sindhi in praise of the great river Indus or Sindh. Another student of Joyo was Rasul Bakhsh Palijo, who graduated from the Sindh madrassab in 1948. He became a schoolteacher in the town of Thatta and later became a lawyer defending Sindhi students and separatists in many controversial court cases. In the I960s, Palijo was one of the most radical leaders of the Sindhi movement protesting against the military regime of General Ayub Khan. A third vocal leader of the Sindhi movement was Jam Saqi, leader of the Sindhi student movement in the late I960s, who later became the leader of the Communist Party. Both Jam Saqi and his father had been students of Ibrahim Joyo, the father at the Sindh madrassab in Karachi, Jam Saqi himself at Sindh University near Hyderabad. Like G.M. Syed's house in Karachi, Joyo's residence in Hyderabad became a meeting place of Sindhi separatists and leftists from the ig6os onwards.

\section{MYSTICISM AND MARXISM COMBINED}

Till the mid-r960s, G.M. Syed's ideas about mysticism and Joyo's Marxism still seemed incompatible, as Joyo, a self-declared materialist, ${ }^{3 \mathrm{I}}$ had little patience with mysticism. Despite their close mentor-pupil relationship, the two men did certainly not agree on everything. Joyo was diametrically opposed to the "syedism" of his G.M. Syed. Like other reformists such as Muhammad Iqbal and Maulana Maududi, he condemned the devotion to spiritual leaders as a form of idol worship (shirk). On a personal level, however, Joyo always remained loyal to the man who had made his higher education possible. Joyo's admiration for G.M. Syed

31. Personal communication with Ibrahim Joyo. 
was made easier because G.M. Syed himself dismissed uncritical commitment to the spiritual leader as wrong. His reform of mysticism was a radical one, leading to the rejection of the various Sufi brotherhoods. As Joyo told me in an interview, "G.M. Syed accepted no guides, only books." In his personal conduct, however, he continued to behave like a syed, wearing white clothes to express his purity and detachment from worldly matters. Till the end of his life, the peasants working on his lands would touch his feet asking for favours. This was unacceptable to Joyo.

When in 1966 his house arrest was lifted, however, G.M. Syed turned to Joyo's group of young Sindhi students in order to return to politics. This turned out to be mutually beneficial. G.M. Syed gave to his new friends his charisma as a syed, a social reformer, and a political leader. In return he received the revolutionary enthusiasm and street power of the young intellectuals. This was the beginning of a new twist to Sindhi nationalism, which combined both G.M. Syed's reformed Sufism and Joyo's interpretation of Marxism, resulting in a powerful and attractive ideology for many young Sindhis.

G.M. Syed encouraged his new friends and "comrades" not to restrict their activities to the university campus and schools. He sent them to the many shrines of local holy men in the rural areas, especially on the annual urs celebration, when the holy man's release from this world is celebrated in colourful festivals that attract many pilgrims. These events were important for several reasons. New intellectuals went back to the rural areas from which they originated, bringing with them a new way of looking at these places of pilgrimage. In the interpretation of G.M. Syed and his group, the holy men were martyrs for the cause of mysticism, Sindh, and the liberation of the peasant. Jam Saqi, the student leader, for instance, wrote a book on one of these local holy men, the eighteenthcentury Shah Inayat of Jhok, calling him somewhat anachronistically a "socialist Sufi". In Saqi's reading, Shah Inayat had been the leader of a commune of liberated peasants, for which he was beheaded. This reinterpretation of holy men as social reformers was a potential threat to many local landlords, pirs, and syeds, who often claimed to be the descendents (sajjada nishin) of holy men, who had inherited part of their miraculous powers (barakat).

In Sindh, as elsewhere in South Asia, traditional Sufism consists of various brotherhoods of holy men (pir), their descendents (sajjada nishin), and their followers (murid). As the sajjada nishin are often landlords, traditional Sufism is related to patron-client relations. By way of speeches, songs, and discussions with fellow-pilgrims, however, G.M. Syed and his group criticized this hierarchical structure of spiritual authority based on inherited charisma. They condemned the patron-client relations that were ritually confirmed and reproduced during the traditional urs. Instead, they tried to turn the local holy men into historical heroes of Sindh and 
prophets of mysticism, with whom the disciples could get in touch through the traditional practices of music and dance. In these mystical encounters they would be able to find the spirit to free themselves from their oppressors, that is, the landlord families, most of whom supported the military government.

Although these activities probably did spread some awareness among pilgrims and peasants about the causes of social inequality, the main effect of these activities was a deeper engagement with mysticism and Sindhi separatism among the Sindhi students and intellectuals themselves. The trips to the rural shrines became important rituals for the Sindhi left. Identifying with the rural fakir and other mystical figures who are so absorbed in the love for God that they are indifferent to pain and fear, they derived from these trips a romantic sense of passion and belonging, which was apparently more compelling than Ibrahim Joyo's belief in the inevitability of progress.

Zulfiqar Ali Bhutto, also a Sindhi, recognized the potential of this reformed Sufism when he founded the Pakistan People's Party to contest the elections of 1970 . He, too, went to the rural shrines, sat down to talk to the peasants and pilgrims, and called himself a fakir. However, whereas G.M. Syed called for the independence of Sindh, Bhutto's ambition was to rule Pakistan, and when he did, he turned some of the shrines in Sindh into places of national, rather than provincial, importance. Attracted by Bhutto's rhetoric of socialism and mysticism, some of the Sindhi leftwing intellectuals joined Bhutto, but most of them were soon disappointed and returned to the Sindhi separatist movement of G.M. Syed. In I973, the latter founded the Jeay Sindh Movement, which, two years after the foundation of Bangladesh, called for an independent Sindhudesh. From then on, G.M. Syed spent most of his life under house arrest. This seriously damaged the Sindhi movement. However, the notion of Sindh's unique identity rooted in a history of mysticism was spread widely. Today, it is commonly understood in Pakistan that Sindh is a place of religious tolerance and mysticism.

A brief note, then, on the question why Bhutto could successfully use the reformation of Sufism for his own project, while the separatist movement of G.M. Syed failed. Due to the Anglo-Saxon system of democracy, in which people vote in districts according to the winnertakes-all principle, people in Pakistan tend to vote for local power brokers rather than along ideological lines. In this way, landlord families have become the most powerful political class in Sindh. The Pakistan People's Party, in particular, relied for many years on the brokerage of local landlords within their districts. It is mainly for this reason that Sindh's new intellectuals and radical politicians have not been able to become an important political factor, even though many people in Sindh were sympathetic to their dual agenda of social reform and the revival of 
mysticism. Till recently, it was not uncommon for Sindhis to have a portrait of G.M. Syed in their house, often alongside a portrait of Zulfiqar Ali Bhutto or his daughter, Benazir. The former was widely admired as a true syed. When it came to voting, however, most people opted for his rivals, the Bhutto family of the Pakistan People's Party. After one of the many elections he lost, G.M. Syed remarked about the people of Sindh: "They sing and dance for me, but they don't vote for me." ${ }^{2}$

The lack of electoral success may have been the reason why the Sindhi separatist movement disintegrated into various smaller parties from the I970s onwards. Nonetheless, the Pakistan People's Party adopted the discourse of peasant liberation and mysticism, for which G.M. Syed and Ibrahim Joyo were largely responsible. In the hands of the Pakistan People's Party, however, this discourse, once meant to bring to power an up-and-coming class of new intellectuals within an independent Sindhudesh, served to confirm the political power of landlord families within Pakistan.

\section{CONCLUSION}

The new intellectuals I have described called themselves secularists because of their rejection of Muslim nationalism. Following G.M. Syed's distinction between religion and mysticism, they rejected the political relevance of religion, that is, religious doctrine and ritual, as well as the authority of the ulama, the mullahs, and the pirs and syeds. I have, nonetheless, called their ideology a specific form of Islamic reform or revival. Whereas some Islamic reformers revived the tradition of ijtehad or the individual interpretation of Islamic sources, and others returned to the sovereignty of the shariat or Islamic law, the Sindhi movement built upon the Sufi notion of wabdat ul-wajud or the oneness of being. Like the other variations of Islamic reform, the claim was to return to the original meaning of the concept, to rationalize it, and to purify it from the corruption of later innovations (bidat). In practice this meant an attack on the hierarchy of religious authority. Whereas other forms of Islamic reform undermined the authority of the ulama and the mullahs, the Sindhi form criticized the Sufi brotherhoods and their leaders, that is, the pirs and syeds who claimed to be the descendents of the founder of the brotherhood. In Sindh, the pirs and syeds used to be the most powerful religious specialists, more important than the ulama.

In this article I have focused on the network of new intellectuals responsible for this peculiar form of Islamic reform. For want of space I have not analysed the wider debates on Islam, nationalism, and ethnicity as

32. Personal communication with Hamida Khuhro. 
they have evolved after independence in the process of nation and state building. ${ }^{33}$ Like most other Islamic reformists, the students, teachers, lawyers, journalists, poets, and social workers who joined the Sindhi movement received their education in secular educational institutions. Most of them were among the first of their social milieu to be trained in these institutions. Their secular education took them out of their environment and into the city - the Sindh madrassab in Karachi and, after independence, the University of Hyderabad. Moreover, they did not only benefit from new education opportunities, they also actively promoted secular education as a means to reform society. Apart from politicians and intellectuals, they also were, and self-consciously wanted to be, teachers, founders of schools and boarding houses, and educational reformers.

Secular education enabled them to look at the villages from which they came in a new way. It also gave them the tools to develop their own kind of Islamic reform. Of particular importance was the reformation of the urs celebration at local shrines. For the new leftist intellectuals, the urs no longer was an occasion in which the authority of the landlord qua pir or syed was confirmed. For them, it rather became an event to commemorate the martyrs of Sindh and its peasants.

Although critical of the state and the state ideology of Muslim nationalism, the Sindhi intellectuals were influenced by other forms of Islamic reform as well as the discourse that links the nation to the religious community. In their own unique ways, they were searching for the essence of Islam, finding it in mysticism, and defining the distinct character of the Sindhi nation on the basis of this mystical essence of Islam. They were, in Gramsci's term, on the defensive, that is, responding to a dominant discourse of religious nationalism, appropriating it to argue for the uniqueness of the Sindhi people within Pakistan. They did so in opposition to an authoritarian regime, initially a military government, followed by a democratically elected regime that was, however, hardly less oppressive than the military rule that preceded it - witness G.M. Syed spending years under house arrest.

However, state oppression was not the main factor that rendered the Sindhi movement powerless. Paradoxically, the movement suffered more from the gradual incorporation of its ideas into official nationalism. In the I970s, the Pakistan People's Party under the leadership of Zulfiqar Ali Bhutto managed to cut the grass from under the feet of G.M. Syed and his followers by reconciling the latter's ideas on ethnicity and mysticism with the notion of religious nationalism. This perhaps shows how close G.M. Syed and Ibrahim Joyo remained to the dominant discourse of Muslim debates. 
nationalism and Islamic reform, despite their efforts to show that Pakistan was a mistake and despite the uniqueness of their interpretation of Islamic reform. In their opposition to state discourse they remained inextricably connected to it. 